\title{
Do passado e do presente
}

\section{A hypothesis on the personal inflection in Boróro}

Aryon Dall'Igna Rodrigues

Universidade de Brasília

This article has been originally published in Anais da $45^{a}$ Reunião Anual da SBPC. "Ciência e qualidade de Vida", Universidade Federal de Pernambuco, 11-16 de julho de 1993, p. 509.

Translation by Ana Suelly Arruda Câmara Cabral and Beatriz Carretta Corrêa da Silva

The Boróro linguistic family is probably a member of the MacroJê stock (Rodrigues 1986, Greenberg 1987). Guérios (1939) had already pointed out similarities between the Boróro language and two languages of the Jê family, the Timbíra ("Merrime") and the Kayapó languages. Boróro is the only well known language of the Boróro family (according to the lexical and phonological correspondences between Boróro and Umutina, of the same family, as demonstrated by Rodrigues (1961/1962)). The main works on Boróro are: Colbacchinni (1925), Colbacchinni and Albisetti (1962), Albisetti and Venturelli (1962, 1969, 1976), and Crowell (1979). Recently, indications of lexical and phonological correspondences between Boróro, the linguistic Tupian stock, and the Karíb family have been proposed by Rodrigues (1985), in a context of a remote past genetic relationship among Tupí, Karíb, and Macro-Jê. In this communication I present what can be considered an additional piece of evidence for the hypothesis on that genetic relationship, specifically associating Boróro with the Jê family, but also highlighting a phonetic analogy with the Tupian stock.

Boróro has nine person markers which indicate the possessor in nouns, the subject and the object in verbs, and the complement of postpositions: 1 . $i$ - 'I', 2. $a$ - 'you', 3.u-/ $\emptyset$ - 'he', 'she', 12. pa- 'we (incl.)', 13. če- 'we (excl.)', 23. ta- 'you (plural)', 33. e- 'they', 3C(o-referential), ti- 'themselves', 3R(eciprocal) pu- 'they, each other' (Crowell 1979:206). Those markers are directly prefixed to all stems initiated by $\mathrm{C}$, as well as to a part of stems with initial $\mathrm{V}$, but some of these have the allomorph $\check{y}$ - instead of $u$ - or $\emptyset$ - for 3.: 1. i-mana 'my older brother', 2. a-mana, 3. u-mana, 12. pa-mana, 13. 
če-mana, 23. ta-mana, 33. e-mana, 3C. ti-mana, 3R. pu-mana; 1. i-ewi 'my forehead', 2. a-ewi, 13. č-ewi. Other stems initiated by $\mathrm{V}$ have a $\mathrm{C}$ inserted between the prefix and the stem, except in 3 and, in general, also in 3C. This $\mathrm{C}$ is $k$ preceding all stems initiated by an anterior $\mathrm{V}$; preceding stems initiated by a back V, C is $k$ only when the person marker finishes in a back $\mathrm{V}$, it is $t$ when the person marker vowel is anterior; when the person marker has an initial $\mathrm{C}, g$ and $d$ occur instead of $k$ and $t$ : 1. i-k-eri 'my tongue', 2. a-k-eri, 3. ฤ-eri, 12. pa-g-eri, 13. če-g-eri, 23. ta-g-eri, 33. e-k-eri, 3C. ti-g-eri, 3R. pu-g-eri; 1. i-t-o 'my teeth', 2. a-k-o, 3. ฤ-o, 12. pa-g-o, 13. če-d-o, 23. ta-g-o, 33. e-t-o, 3C. t-o $(<t \mathrm{i}-o), 3 \mathrm{R}$. pu-g-o. There is a subset of stems initiated by back $\mathrm{V}$, which, instead of $t / d$ have $n$ after the person marker with an anterior V: 1. i-n-ogwa 'my lip', 2. a-k-ogwa, 3. Ø-okwa, 12. pa-g-ogwa, 13. če-n-ogwa, 23. ta-g-ogwa, 33. e-n-ogwa, 3C. t-ogwa, 3R. pu-g-ogwa.

Besides the stem for 'teeth', which intercalates $t$, there is another stem $o$ 'unalienable possession', which intercalates $n$ : 1. $i-n-o$ 'my unalienable possession', 2. a-k-o, 3. ฤ-o, 12. pa-g-o, 13. če-n-o, etc. This stem is probably cognate of Timbíra(Jê) $\tilde{o}$ with the same meaning (Rodrigues 1992). Comparing Boróro paradigm (Crowell 1979) with the Timbíra (Souza 1990), we notice particular affinities among them: B $i-n-o$, T $i y-\tilde{o}$ [iñõo], B. $a-k-o, \mathrm{~T}$. $a y-\tilde{o}$ or $\eta-\tilde{o}, 3$. В. $\emptyset$-o, T. $h$ - $\tilde{o}$. The form for 3 may be a perfect correspondence between the two languages. B. does not have a phoneme $h$, nor nasal vowels. The hypotheses that I propose to identify historically the paradigms of B. and T. is the following: Among the phonological changes which have characterized B. as it is at present, the following changes have occurred: (a) $y$ changed to $k$ (probably through $w$ and $k^{w}$ ), preceding a front $\mathrm{V}$, and also before a back $\mathrm{V}$, when preceded by another back V; (b) $y$ changed to $t$ or $n$ between an anterior $\mathrm{V}$ and a posterior $\mathrm{V}$, according to the original nasal or oral phonemic status of this $\mathrm{V}$; (c) all nasal vowels underwent denasalization. The change from $y>w$ or vice-versa is well known from other linguistic domains; the correspondence between the prevocalic $y$ from Tupí-Guaraní with Tuparí $w$, is an illustrative case of this: Tupinambá yakú, Tuparí wako 'jacu'; Tb. ayuru, Tr. a(w)oro 'parrot', Tb. yeke?a 'fishtrap', Tr. wekẽe?a, Tb. $y \dot{\mathrm{i}}$, Aw. $k \dot{\mathrm{i}}$ ' $\mathrm{ax}$ '. Also the change involving $y, t$, and $k$ is known in the Tupian domain: Awetí has $k$ corresponding to Tupí-Guaraní $y$ before an unrounded high $\mathrm{V}$, and it has $t$ before other $\mathrm{V}(\mathrm{s})$ : Tb. $y \dot{\mathrm{y}}$, Aw. $k \dot{\mathrm{i}}$ 'ax', Tb. peyu, Aw. petu 'to blow', Tb. yaku, Aw. taku 'guan'. 


\section{References}

Albisetti, C.; J. Venturelli. 1962. Enciclopédia Boróro, vol. I: Vocabulários e Etnografia. Campo Grande: Museu Regional Dom Bosco.

Albisetti, C.; J. Venturelli. 1969. Enciclopédia Boróro, vol. II: Lendas e Antropônimos. Campo Grande: Museu Regional Dom Bosco.

Albisetti, C.; J. Venturelli. 1976. Enciclopédia Boróro, vol. III: Textos dos cantos de caça e pesca. Campo Grande: Museu Regional Dom Bosco.

Colbacchinni. 1927. I Bororos Orientali. Orarimugudoge del Mato Grosso (Brasile).Torino: Società Editrice Internazionale.

Colbacchini, A.; C. Albisetti. 1942. Os Boróros Orientais - Orarimogodógue do Planalto Oriental de Mato Grosso. São Paulo: Companhia Editora Nacional.

Crowell, Thomas Harris. 1979. Grammar of Bororo. Tese de doutorado, Cornell University.

Greenberg, J. H. 1987. Languages in the Americas. Stanford: University Press.

Guérios. R. F. M. 1939. O nexo linguístico Bororo-Merrime-Caiapo, Revista do Ciclo de Estudos Bandeirantes 2.61-74.

Klein \& L. R. Stark (eds.), South American Indian languages: retrospect and prospect, p. 371-404. Austin: University of Texas Press.

Rodrigues, Aryon Dall'Igna. 1961/1962. Comparação das línguas Umutína e Boróro. Revista do Museu Paulista 13:99-108.

Rodrigues, Aryon Dall'Igna. 1985. Evidence for Tupí-Karíb relationships. In Harriet M. Klein; Luisa R. Stark. (org.), South American Indian languages: retrospect and prospect. Austin: University of Texas Press, 1985, p. 371-404.

Rodrigues, Aryon Dall'Igna. 1986. Linguas Brasileiras: para o conhecimento das línguas indígenas. São Paulo: Edições Loyola.

Rodrigues, Aryon Dall'Igna. [1992] 2009. A case of affinities among Tupí, Karíb, and Macro-Jê. Revista Brasileira de Linguística Antropológica, I, Brasília.

Rodrigues, Aryon Dall'Igna. 2001. Flexão relacional no tronco linguístico Macro-Jê. In: M. E. Soares (org.) Boletim da ABRALIN. 25:219-231.

Souza, S. M de. 1990. O sistema de referência pessoal da língua Krahô. Dissertação de Mestrado, Universidade Estadual de Campinas. 